\title{
Klagenfurt School of Engineering Pedagogy by Adolf Melezinek as the Basis of Teaching Engineering
}

\author{
http://dx.doi.org/10.3991/ijep.v6i3.5949 \\ Tiia Rüütmann, Hants Kipper \\ Tallinn University of Technology, Tallinn, Estonia
}

\begin{abstract}
Engineering Pedagogy is an interdisciplinary scientific subject and an essential element of the system of engineering education. The article is dedicated to the work of Adolf Melezinek, the founder of Engineering Pedagogy and the main principles of Kalgenfurt School of Engineering Pedagogy. Curriculum design and technical teacher education in Estonia is based on Melezinek's work. A decision-making model by Urve Läänemets, closely connected to Melezinek's work and the Model of Flexible Technical Teacher Education and contemporary methodology are introduced.
\end{abstract}

Index Terms-engineering pedagogy; technical teacher education; model; curriculum; teaching engineering.

\section{INTRODUCTION}

„Scientists dream about doing great things. Engineers do them. " James A. Michner.

Professor Adolf Melezinek (1932 - 2015) was the founder of International Society of Engineering Pedagogy (IGIP), long-time president of IGIP, IGIP honorary life president and one of the founding professors of the University of Klagenfurt.

Adolf Melezinek had numerous international honors and activities - among others Advisor to the Government of the Czech Republic for higher education, Honorary Doctor of Tallinn University of Technology, Honorary Senator of the University of Budapest, Honorary Doctor of Technical University of Liberec, Moscow NE TU Bauman, University of Hradec Králové, Technical University in Moscow (MADI), etc.

The present article is dedicated to the work of Adolf Melezinek, the main principles of Kalgenfurt School of Engineering Pedagogy, curriculum design and technical teacher education in Estonia based on Melezinek's work.

\section{DeVelopment of EngineERING PEDAGogy}

Adolf Melezinek was the founder of the Klagenfurt School of Engineering Pedagogy. The fundamental principles of Engineering Pedagogy Science have been elaborated, and formulated in general sense by Adolf Melezinek [1]. Engineering Pedagogy is an interdisciplinary scientific subject and an essential element of the system of engineering education.

While scientific pedagogy comprises various schools and streams, two major streams can be identified based upon simplified and generalized assumptions. The first one includes the more or less traditional philosophical- spiritual scientific beginning during which methods based upon phenomenological understanding were applied in order to get insight into the components of the instruction process. The other stream is represented by scientists who basically created the cybernetic beginning during which calculation methods dominated. Although both the streams comprise a wide range of schools, they share certain key ideas which, at the same time, distinguish them from each other [3].

The traditional, classical pedagogy did not meet specific needs when used for education of engineers striving for the teaching profession. This was proved by experiences of different countries. The discrepancy was solved by setting up of special engineering-pedagogical institutes at some technical universities. The term "Ingenieurpädagogik - Engineering Pedagogy" has become a technical term for a young scientific discipline which deals with the problems of teaching technology.

The term "Engineering Pedagogy" signifies the characteristic of discipline - the interaction of engineering and technical sciences with pedagogy and the education system. As it is presented in Figure 1 (in Melezinek [2]), the necessary technical knowledge is offered to Engineering Pedagogy by different technical sciences. Pedagogical knowledge (didactics) is generally used in the development of corresponding knowledge systems for instruction, as well as for the method of instruction, whereby the cognitions of other sciences are also being used, such as psychology, sociology, information theory, etc.

Melezinek [3] proposed the aims of Engineering Pedagogy - to implement integral thinking in terms of Science as Art, trying to combine the science of teaching with the art of the teacher, i.e. with the teacher's personality. The teaching process should be inspired in a scientific manner applying as many calculation methods as possible and making teaching activities meaningfully algorithmic. However, human beings and art, which inspires teaching and adds creativity, should maintain their roles in the instruction process. The teacher's art should be applied in accordance with the science, exploring the effectiveness of teaching processes. The subject of engineering pedagogy is everything, which improvement of technical disciplines is aimed at, all kinds of teaching activities, concerned with aims, content and forms of education.

The methodology of engineering pedagogy as the science of the most common laws, principles and methods of scientific and technical knowledge, search for new ideas and theories and their realization, the contents and structure of engineering activities has been considered. The 


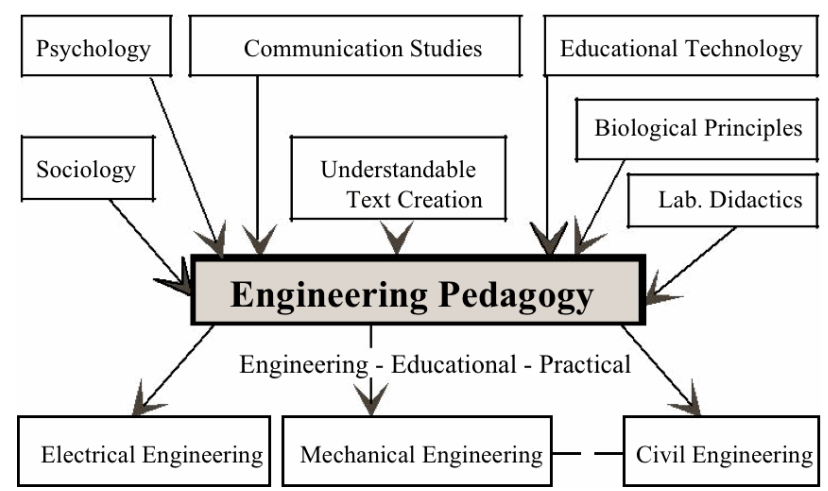

Figure 1. Engineering Pedagogy Model for Technical Teacher Training [2]

object of engineering pedagogy is the pedagogical system of training engineers; the subject is described as designing and realizing of professional training contents, organization forms, methods, the process of specialist's personality formation. The basic notions and categories are the same as in general pedagogy: aims, principles, organization form, etc, enriched with new contents taking into account the objectives of engineering education. The categories specific for engineering pedagogy are scientific and technical knowledge, engineering activity, specialist's personality and communication in the process of professional activity.

\section{DEVElopment OF ENGINEERING PEDAGOGY SCIENCE}

According to Heinze [4] developments in engineering pedagogy in Europe in 1950s are exemplified by three "schools of Engineering Pedagogy":

- the "Dresden school of Engineering Pedagogy";

- the "Prague school of Engineering Pedagogy";

- the "Klagenfurt school of Engineering Pedagogy".

The "Dresden school of Engineering Pedagogy" goes back to the founding of the Institute of Engineering Pedagogy at the Technical University in Dresden in November 1951 [2]. The first director of the institute was Prof. Dipl.-Ing. Hans Lohmann, succeeded by Prof. Dr. Lichtenecker in 1963 and Prof. Dr. G. Lehmann in 1986 [3].

The "Prague school of Engineering Pedagogy" developed in Czechoslovakia in the 1960 s based on activities at the universities in Prague, Liberec, Brno, Olomouc, Bratislava and Kosice. An Institute of Vocational Training was set up at the Technical University in Prague in 1961, which became the Institute of Studies at Technical Universities in 1965. The director of the institute was Prof. Dipl.-Ing. S. Novák, CSc [3]. Thus the origins of the "Prague school of Engineering Pedagogy" can be clearly dated back to 1961 . The origin of this institute existed in different forms till 1991, when its educational activities were taken over by the new founded Masaryk Institute of Advanced Studies of Czech Technical University in Prague. The work of Prof. S. Novák was continued by on by Dr. Dipl.-Ing. J. Měřička and PhDr. Dana Dobrovcká Csc [3]. Development and production of new educational means in the institute were closely connected with research.
The "Klagenfurt school of Engineering Pedagogy" was established in 1971. Dipl.Ing.,Dr.phil.,Dr.hc. Adolf Melezinek was appointed to the "chair of the didactics of scientific/technical subjects with particular reference to teaching technology' and University of Educational Sciences (now the University of Klagenfurt) saw the continual and systematic scientific development of engineering pedagogy in Austria [2]. The term "Klagenfurt School of Engineering Pedagogy" is used for a scientific approach founded by Adolf Melezinek.

According to A. Haug [5], Melezinek built up the Institute of Teaching Technology with an emphasis on engineering education. Melezinek had previously been based in Prague where he taught courses for technology lectures at university level at TU. Thanks to these activities and IGIP, the work of the "Klagenfurt School of Engineering Education" was and is still very effective.

According to Victor K. Schutz [6] the "Klagenfurt school of Engineering Education" and IGIP are well established. They should be able to contribute significantly along with the Bologna Declaration, the ABET CRITERIA and other programs to an eventual accreditation agreement for engineering and technology programs and faculty members.

The current situation of engineering pedagogy has evolved more or less continuously from activities at the three schools of Engineering Pedagogy mentioned above. This is where the basic approaches of all three schools of Engineering Pedagogy meet: the prerequisite for scientific studies on engineering pedagogy is mastery of the fundamentals of a technical science subject. The path to teaching a science irreversibly leads from mastery of the subject matter to the actual teaching process. This is where specific research on engineering pedagogy can start. Naturally, it also reflects findings from pedagogy and other sciences and takes account of a whole series of important influences [2]. This is formulated in a general sense by Melezinek [1] in the initial approach of the "Klagenfurt school of Engineering Pedagogy" when he defines the subject of engineering pedagogy as the scientific investigation and practical realization of the aims and contents of technical subjects as well as of the process in which their contents are transformed by specific media as influenced by a specific socio-cultural environment with the help of specific teaching methods with the knowledge of specific recipients.

According to Melezinek [5] the Klagenfurt approach to engineering pedagogy may be based on the thoughts of traditional philosophic-humanistic pedagogy, but it does emphasize the approach of cybernetic pedagogy, which is based on the concept of information with its quantitative measurements and feedback control system - in line with the special situation of technical sciences and technicians.

As Melezinek has pointed out [5], the educational process should be scientific - a sensible algorithm should be created for the activity of teaching - but we should not lose sight of the person and their art which inspire teaching and give it creative impulses. The art of teaching should be brought to bear on the foundations of a science on the effects of learning processes.

The "Klagenfurt School of Engineering Pedagogy" defines the subject of engineering pedagogy as the scientific investigation and practical realization of the objectives and contents of technical subjects as well as the process in 
which the subject matter is transformed into knowledge for the addressees with the help of certain media and instructional methods within a socio-cultural environment [1].

The engineering pedagogical concept of teaching according to Klagenfurt approach may be described as follows: education is a subject to certain regularities. It has two poles - the teaching system and the learning system between which information is transferred.

According to Frank and Heimann the course of the whole process is influenced by a number of variables [1]:

- Instructional objectives (Z);

- Subject matter (L);

- Psychostructure (P);

- Media (M);

- Sociostructure (S);

- Teaching method (LM).

Teaching can change significally when the variables are altered. The teacher's main didactic task is to find an optimal teaching method (LM - how?) which can achieve a given instructional objective ( $Z$ - why?) for a given subject matter $(\mathrm{L}-$ what?) with the available media $(\mathrm{M}-$ with what?) for the addressees present $(\mathrm{P}-$ who?) under the influence of a certain socio-cultural environment ( $\mathrm{S}$ where?). This described Engineering Pedagogical model of the teaching process is presented in Figure 2 [1].

The teaching method is thus a function of different influential factors and can be expressed mathematically as follows [1]:

$$
\mathrm{LM}=\mathrm{f}(\mathrm{Z}, \mathrm{L}, \mathrm{M}, \mathrm{P}, \mathrm{S})
$$

This functional equation describes very complicated relations as all factors act together. Individual factors can act with or against others. The educational process as a whole, taking account of teaching and learning and the mutual interplay of all pedagogical variables, represents an extraordinary complex construction.

In the process of teaching the forming of knowledge of students is always carried out by a certain plan, according to the accurately specified instructional objective. Taxonomy of instructional objectives was developed by B. S. Bloom, D.R. Krathwohl another authors (cited in [1]). According to the formulation of R. F. Mager it is possible to understand the instructional objectives of the teacher set as univocal, clear-cut, excluding most of alternatives (cited by [1]). According to Melezinek [1] it is important first to set general instructional object and then detailed instructional objects of a lecture.

Clear conception of the goal before learning study materials provides the learners with the opportunity to explain the reference points of joint activity and to make clear the tasks challenging them. This takes off the stress during the process of teaching, promotes motives formation and finally increases teaching effectiveness.

Pedagogical variable "subject matter" indicates what should be taught to students. H. Frank and B. Meder (cited in [1] have proposed the change of the amount of scientific information in years. At the end of 18 th century the amount of scientific knowledge overcame the possibility of seize of a single person. The structural-theoretical approach of Jerome Seymour Bruner (cited in [1]) proposes that the old image of a science as a quantum of exactly described facts has expired, and contemporary science is

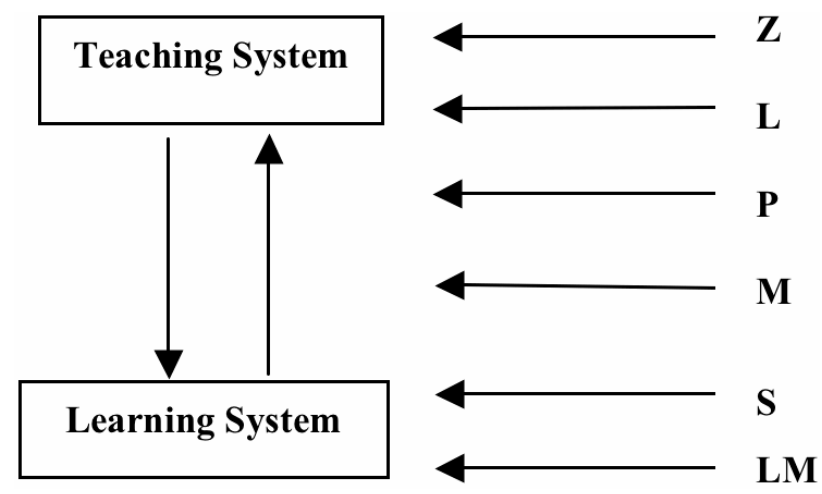

Figure 2. Engineering Pedagogical Model of the Teaching Process [1]

more than collected and generalized facts. Today new facts have been searched along with phenomena in order to find the conjunction between them for the purpose to finding the structure and systematic effects.

By including separate facts and phenomena into the substantial inner structure of the subject matter, it is easier for students to remember these facts and phenomena with the help of remembered general impression. According to Melezinek [1], a lecturer has to select subject matter according to the aimed instructional objective and point out the main phenomena, laws and conceptions and to structure the chosen subject matter, use main principles of the conception of understandability.

The invariable "psycho-structure" has also great importance in engineering pedagogy. This is formulated by Melezinek [1]. G. Gagne [1] has defined the process of teaching - teaching is a goal-directed process of transmission of knowledge, the result of which residual changes in human reserves or abilities have occurred, and which have not occurred due to the natural development.

The main condition for the learning process is receiving information from surrounding. Information is received by optical, acoustical, tactile, thermal, and sensoral channels. The intensity of the appropriate channel refers to the maximum of information that these channels transfer in unit pf time to sensoral memory.

According to H. Frank (in [1]) maximal intensity of optical channel is $107 \mathrm{bit} / \mathrm{s}$, that of acoustical channel is about $1,5.106 \mathrm{bit} / \mathrm{s}$, and tactile channel (only by hand) $0,2.106 \mathrm{bit} / \mathrm{s}$. Intensity of other channels is much lower and stay in the interval from 10 to $100 \mathrm{bit} / \mathrm{s}$. The speed of apperception is defined by H. Frank 16 bit/s. H. Riedel proved that the speed of apperception depends on the age of people. H. Frank noted the value $16 \mathrm{bit} / \mathrm{s}$, which is maximal for people in age of $18-21$. H. Frank stated that information in short-term memory the delay is 10 seconds, at the same time according to the data of H. Riedel it is 6 seconds. The flow speed into permanent memory according to H. Frank and F.V. Cube is 0.7 bit/s [1]. According to Melezinek [1] a lecturer must not be in haste, it is important to use short sentences, repeat subject matter, especially the most important parts, ask students to make written remarks, use problem-solving, make pauses, consider the time of a lecture (from $2 \mathrm{pm}$ to $4 \mathrm{pm}$ avoid monodirectional activities).

Important variable is socio-structure, characterizing socio-cultural environment of origin of the students, and socio-cultural environment where the process of instruction is carried out. Important are the age, gender, sphere of 
activities, and peculiarity of place of living, financial conditions [1]. It is also advisable to know the foregoing study experience of the students which are important in setting basic requirements.

Teaching assumes presenting of different information. Under the term "Media" all technical devices, equipment and systems, which facilitate the process of teaching are considered. Methodology of using media is dealing with soft media (using methodology) and hard media (devices, apparatus). Media could be divided into adaptive (for bidirectional communication - separate lessons, lessons with groups or parallel groups) and un-adaptive (for mono-directional communication - visual, audio and audiovisual information). Basic and important data concerning requirements for a lecture hall and visual and audiovisual media have been calculated and presented by Melezinek [1]. According to Melezinek, a lecturer has to choose appropriate media adequate to instructional objectives, check how devices work already before the beginning of a lecture, check over that all the students can see images on the display, guarantee readability of fonts used in projection, use colors functionally, present information in essential moment, check illumination of a lecture hall, guarantee audibility of a speech [1].

Correctly chosen teaching methods facilitate the optimal way which helps students to reach aimed instructional objectives. Teaching process is based on communication processes. Very important in teaching process are oral and visual communication. But of especial importance is easily understood communication. Conception of understandability has been presented by Langer and Schulz, Thun and Tausch [1] suitable also for technical information. Langer and Schulz, Thun and Tausch define four features of understandability: simplicity, regularity, orderly-structured (divided into parts), and concision of presentation and additional stimulation. Teaching methods could be divided into inductive and deductive. According to $\mathrm{K}$. Geiger (cited in [1]) teaching methods could be divided into inductive methods and deductive methods.

In the process of teaching methods' choice the teacher should combine the form, contents and methods of carrying out the teaching process on the base of information available. It is recommended to represent them as a table on the initial stage after main teaching methods' choice; the table should combine the activity on every stage of mastering and the teaching methods. As a result the teacher's final product of methodical activity on the choice of teaching methods represents a table of chosen teaching methods, plan of lessons and themes. Lesson's structure and also different descriptions of teacher's activity and means for carrying out students' activity on should be analyzed on every stage.

According to Melezinek, [1] a lector should choose teaching methods accordingly to the general system of communication: formulate instructional objectives, choose appropriate subject matter, assess psycho-structure and socio-structure of students, choose adequate media and teaching methods. For proving essential laws inductive methods should be used, for proving special laws (if students are unaware of general laws) inductive method is recommended to use. For proving solitary laws if general laws are known for students, both methods - inductive and deductive may be used, but it is recommended to prefer deductive method, as it shows interdependency with other laws.
The teaching of engineering pedagogy is very closely linked with the development of theories on engineering pedagogy. The Institute of Engineering Education at the TU in Dresden has put on various courses over the years. For example, starting in 1958, a course on engineering pedagogy for teachers at technical colleges was offered as an additional qualification. The admission requirements for this course included a university degree (Dipl.-Ing) and at least two years full-time teaching experience at a school of engineering. Graduates of this course received a certificate for this "additional pedagogical examination". From 1976 onwards it ran as a "postgraduate course on technical college pedagogy".

\section{IGIP BASIC CURRICULUM FOR ENGINEERING PEDAGOGY}

Melezinek has defined very precisely contemporary requirements to technical teachers: "A technical teacher must possess a variety of qualities needed for performing his/her professional functions. A technical teacher must have a high scientific potential, deep fundamental and special engineering knowledge, methodological, pedagogical and organising skills. Besides, possessing the skills of rhetoric, communication, psychological influence, educating is extremely desirable. The content of educational engineering programmes is so complicated and advanced educational technologies are so intensive that a technical teacher may have a success only in case of being able to explain dearly and briefly themes difficult for understanding. $\mathrm{He} / \mathrm{she}$ must also possess un-verbal means of communication: mimetic movements, expressive gestures and fluent speech. In addition to all mentioned above, a technical teacher must possess freely at least one widely spread foreign language, as well as modern technical educational means and practical skills of engineering work." According to this technical teacher training at universities is of essential importance.

In times of increasing European integration it has been necessary to formulate a common minimum standard or well-balanced competence profile for technical teachers. The International Society for Engineering Education has created a register of "International Engineering Educator ING-PAED IGIP”.

The qualification profile is based on three fundamental premises [3]:

- A solid foundation in engineering disciplines is and essential requirement;

- A good knowledge of the pedagogy of engineering education is just as important. The content of appropriate training course should be based on the model of "Engineering Pedagogy" and curriculum can only be taken at institutions approved by IGIP;

- A further requirement for inclusion on the register is a minimum of one year's practical work in the field of engineering education (e.g. technology lecturer, in-service trainer, etc).

International Society of Engineering Education IGIP was founded in 1972 in Klagenfurt, Austria. Over last 35 years the society has developed into an important and well- known international association, being also a member of International Federation of Engineering Education Societies (IFEES). Today, IGIP has members in more than 75 countries, is recognized as a consultative body by 
UNESCO and UNIDO and its publications on engineering education appear regularly.

In May 1972 the first international engineering pedagogy symposium took place in Klagenfurt. On the occasion of this conference, the International Society for Engineering Pedagogy (IGIP) was founded. Since then, international engineering pedagogy symposiums have been held every year.

One of the most urgent problems which IGIP faced in its work was the issue of technical teacher training. IGIP has created ING-PAED IGIP Register (see IGIP www.igip.org ) based on a minimum qualifications profile for teachers and trainers in engineering education. At the major "Second European Conference on the Assessment and Accreditation of Engineering Training and Qualifications" in December 1994 in Paris, the register of INGPAED IGIP was officially recognized as a basic qualifications profile for lecturers in technical subjects. On the suggestion of UNESCO Paris, the register was presented in May 1995 in Sao Paulo and Rio de Janeiro and met with and enthusiastic response [4].

After many years of experience in industry or research, engineers who are appointed as teachers at a technical school or university are influenced by their professional careers. Their way of thinking is determined by the precision of the technology by their work with quantifiable, measurable events and objects. The influence of their discipline, the "language" of engineers, must be taken into account in their engineering education training; it must penetrate the engineering education curriculum [7].

The target group should acquire the necessary professional competences of an engineering teacher. These general, professional competences consist of two main groups: technical expertise and typical engineering education science competences in the narrower sense of the term [8], [9], [10].

The proven IGIP engineering education curriculum is built on the knowledge from traditional education in philosophy and the liberal arts but respects the particular character of the technician and the analyticalmethodological approach in the fields of engineering science.

The engineering educational competences are to be summarized as follows:

- Pedagogical, social, psychological and normativeethical competences;

- Didactic skills and subject expertise;

- Evaluative competences;

- Organizational (Management-) competences;

- Communication and social competences;

- Self-reflexive and development competences.

The contents of the subjects are briefly outlined below with the number of lessons for the different subjects. Altogether the curriculum contains minimum 20 ECTS credits. Compulsory subjects are in the total amount of 17 ECTS credits additionally there are elective subjects in the minimal amount of 3 ECTS credits.

In the proven IGIP engineering educational curriculum there are the following compulsory subjects:

Fundamental principles of Engineering Pedagogy (2 ECTS credits): the core module is the backbone of the curriculum - the base and integrating part of the engineering education science "Technical Teacher Training." The starting point is practically oriented technical teaching. This is understood as a process which, like any other, is subject to specific regularities and is determined by a series of components throughout its course - teaching goals $(\mathrm{G})$, teaching materials $(\mathrm{T})$, teaching media $(\mathrm{M})$, psychological structure $(\mathrm{P})$, social structure (S) and teaching methods (TM) have a complex interdependent relationship [1]. The subject is dealing with the definition of the overall and precise objectives of a lecture, the selection and structuring of information, the different influences of technical subject matters on teaching methods - definition of terms, derivation of laws, inductive and deductive methods, programmed instruction, etc.

Engineering Pedagogy practice (3 ECTS credits): The participants are supposed to practice the design and performance of instructional units using concrete technical subject matters. Their actual performance is recorded on videotape and discussed by the group. Due to their shared experience the transfer of the learnt into real situations is achieved.

Fundamental principles of educational technology, ICT, media and e-learning (3 ECTS credit): Technical devices, equipment and systems used to support instruction. The operation of these media and e-learning, their sensible use and integration into the instructional process are the main problems dealt with in this unit.

Laboratory didactics (2 ECTS credits): Concentrates on psycho-motor aspects of technical classes, namely experimental technical work and research. Amongst others, the structure of controlled experiments should be brought across, i.e. "stating the problem, setting up hypotheses, carrying out the actual experiment, results and conclusions", as well as the various possibilities for teaching work in the laboratory, i.e. "strictly predefined experiments - selecting one experiment from many individual topics selected by students - semester work in the laboratory", etc.

Scientific writing (1 ECTS credit): students should fulfill the requirements of research work. Scientific work at the Bachelor level is usually the first research work of the author, the topic is therefore generally rather narrow which facilitates achieving the desired insight.

Presentation and communication skills (2 ECTS credits): students will acquire basic historical and theoretical-pragmatic knowledge and skills from the field of history of rhetoric, speech technique, and vocal hygiene; by practicing they will develop aesthetic criteria for assessing verbal communication.

Rhetoric (2 ECTS credit): rhetoric should encourage awareness of the effects of speeches and lectures and at least touch on the basic problems of voice training and correct articulation, starting with the fundamentals of clarity to the fascinating persuasiveness of speech. It should be considered in the context of the communication and discussion training and should also be applied to this purpose.

Engineering Ethics (1 ECTS credit) as a study course, Engineering Ethics is closely related to Philosophy. The goal is to offer general information on European thinking advancement in the cultural-historical framework from the beginning of continental philosophy to the present. Theo- 
ries of the human and problems of morality are considered.

Working with projects (1 ECTS credit) - one of the objectives of the teacher project is to have a clear relationship to a teaching experience. If a student chooses to process a textbook, it must include a didactic analysis of existing textbooks (rationale for creating a new text) and pedagogical-psychological parameters required from the textbook. If the author decided on research survey on selected issue, it is usually on a small scale investigation. Its implementation and interpretation, however, must meet all the requirements for such surveys.

Intercultural competencies (1 ECTS credit): the goal of the course is provides students with knowledge of sociopedagogical issues, focusing on the so-called multicultural education, whose mission is to eliminate barriers, prejudice and xenophobia resulting from ignorance of foreign cultures, nations and ethnic groups.

Fundamental principles of psychology (2 ECTS credits): Conditions of human learning, the process of learning, results of memory research, motivation, talent and educability (technical knowledge, comprehension and intelligence), etc.

Fundamental principles of sociology (1 ECTS credit): Functioning and dependence of social groups (classroom community as a social group, groups within school classes), the role concept of the teacher in his professional situation, teacher behavior, student behavior, etc.

Additionally the following elective subjects are taught: Portfolio Assessment; Coaching and Mentoring in Engineering Education; Creative and Critical Thinking; Teamwork and PBL; Standards and Quality in Engineering Education; etc.

\section{TEChNiCAL TEACHER EdUCATION IN Estonia}

In Estonia Estonian Centre for Engineering Pedagogy at Tallinn University of Technology (TUT) was founded in 1995 with the support of Adolf Melezinek. The centre is acknowledged by the Ministry of Education and Research and all public law universities of Estonia. In the same year IGIP Estonian National Monitoring Committee was founded. In 2003 Estonian Centre for Engineering Pedagogy was awarded a title of Engineering Education Training Centre for International Engineering Educators and was accredited by IGIP. The mentor of the centre has been Adolf Melezinek. From 2000-2006 in-service courses for technical teacher education started in cooperation with University of Tartu. Students with higher engineering education with at least Bachelor degree in engineering already working as a teacher are accepted to these courses. From 2006-2012 TUT had an independent curriculum for technical teacher education on master level. The graduates were awarded a certificate of a technical teacher and they could apply for ING.PAED IGIP qualification. Since 2012 continuing education for technical teachers has been carried out at TUT.

The curriculum for technical teachers at Estonian Centre for Engineering Pedagogy, based on the principles of Klagenfurt School of Engineering Pedagogy concentrates on interactive lectures and inductive teaching methods. Different active methods, suitable for teaching engineering, are taught in interactive lectures in the teaching process of the study program, mainly in the subject of the Engineering Pedagogy Science in Theory and Practice.

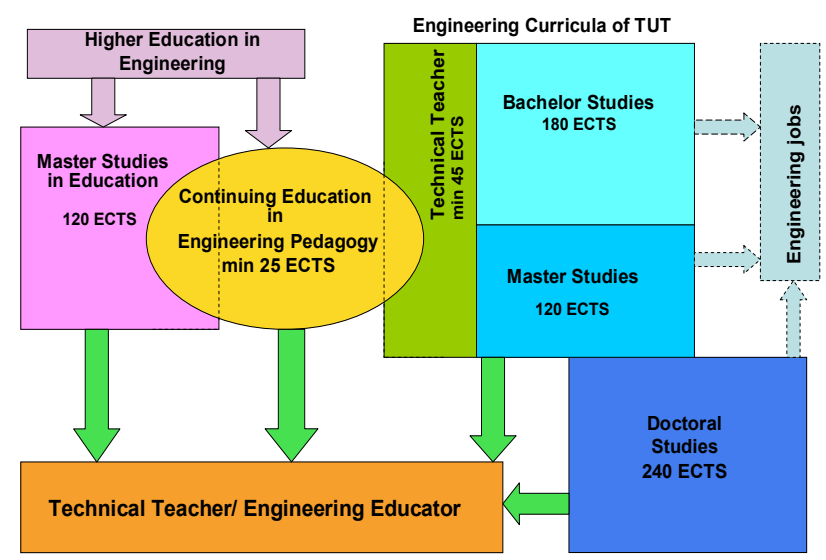

Figure 3. The Model of Flexible Technical Teacher Education at TUT

TABLE I.

STRUCTURE OF THE CURRICULUM

\begin{tabular}{|c|l|c|}
\hline No & \multicolumn{1}{|c|}{ Modules } & $\begin{array}{c}\text { ECTS } \\
\text { credits }\end{array}$ \\
\hline 1 & Engineering Pedagogy in Theory and Practice & 5 \\
\hline 2 & Laboratory Didactics & 2 \\
\hline 3 & Psychological and Sociological Aspects & 3 \\
\hline 4 & Ethical Aspects and Intercultural Competencies & 1 \\
\hline 5 & Rhetoric, Communication and Scientific Writing & 3 \\
\hline 6 & Working with Projects: Curriculum Analysis & 1 \\
\hline 7 & Media (Teaching Technology) and E-Learning & 1 \\
\hline 8 & Multicultural Learning Environment & 1 \\
\hline 9 & Electives & 3 \\
\hline & Total & $\mathbf{2 0}$ \\
\hline
\end{tabular}

These methods motivate students to learn more effectively, providing teaching techniques which address all learning styles.

Technical teacher education in TUT is based on the model of flexible teacher education (Figure 3). The central idea of the model is the basic curriculum of IGIP in the minimal amount of 20 ECTS. IGIP basic curriculum is the basis of the following curricula at TUT:

- master curriculum for technical teachers ECTS);

- the curriculum of continuing education of technical teachers (25 ECTS);

- the curriculum of continuing education for teaching staff (faculty) of TUT (25 ECTS);

- the curriculum of additional specialty of a technical teacher for the students of TUT on bachelor, master and doctoral level (45 ECTS);

- the curriculum of technical teacher education of additional specialty for engineers (25 ECTS).

The main common subjects of the different paths of the model have been presented in Table 1.

Electives (each 1 ECTS) are the following: Portfolio assessment; Creative and Critical Thinking; Coaching and Mentoring in Engineering Education; Team-based and Problem-based Learning.

Informed decision-making for formulating educational policy at the global, regional or local levels has become increasingly complicated due to the changes we are facing 
culturally, economically and productively in the $21^{\text {st }}$ century. Intellectual capital, both individual and social, which is expected to be developed through lifelong learning, is also considered to be an active force in creating economic growth and welfare in all societies. Accordingly, the abilities and skills needed to produce, develop and manage knowledge and innovations are of crucial significance for all modern societies.

Different kinds of social mobility require new comptencies, which means that new educational demands for specific qualifications has to be met by educational policy making, creating opportunities for training and educating requisite specialists. Engineering education has become a priority as the need for technological and science related competences has increased considerably. Technological innovation has also created new environments for research in the field of social sciences as well as practical routine activities. Accordingly, the questions relevant to the organisation and functioning of educational systems require new answers.

The decision-making model has been designed, discussed and experimentally used mostly for curriculum planning and design since 2000 by Urve Läänemets in Estonia; it was first published in 2012 in Hilda Taba 100 Conference book of abstracts by Läänemets [11]. We have since developed new ideas for further implementing it as an integrated system of single or multiple variables, which meets the needs of changing conditions related to organising learning, or other decision making. The basic model is presented in Figure 4.

These seven questions provide answers to the basics of educational planning, including educational policy making, curriculum development and design and its implementation at institutional levels.

The question "why?" requires specification of the aims and goals at different levels. The question "what?" entails informed decision-making concerning the content of education/leaning that is expected to produce the desired knowledge, skills and broader integrated competences of the learners? The selected learning content has to be based on principles specific to each discipline. The "who?" questions requires an analysis of the students and teachers involved in the process of learning. The initial level of learners has to be considered as well as their individual zones of proximal development. The initial level for engineering students starting their university studies has to be a specified body of knowledge and skills in math and sciences acquired at upper secondary level of general education. The other agent - the teacher - who is responsible for organising the studies, has to be a professional and an intellectual at the required level, a specialist who is well informed not only about the content of learning, but who is also knowledgeable about learning theories and instructional psychology in general, and about how to exploit opportunities offered by different learning environments [11].

The answers to the question "how?" describe the potential methods of teaching and learning that can be used for acquisition of the selected learning content. The "how much?" question requires specifying time as a resource allotted for learning in hours, courses etc. Time is perhaps the most crucial resource, which, if spent unwisely, can never be recouped. The amount of contact hours with lecturers/teachers has rarely been considered sufficient,

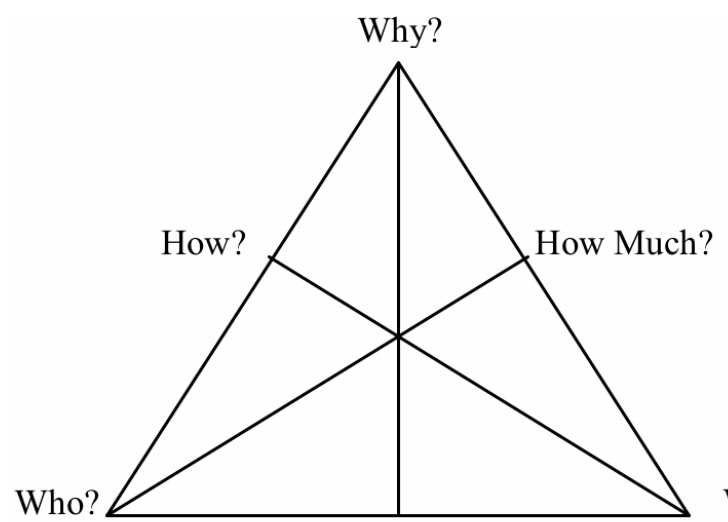

What?

When?

Figure 4. The Decision-making Model by Urve Läänemets [11]

especially at present, when virtual learning environments enable learning in any place at any time. However, the value of human communication cannot be underestimated, especially when tutoring or mentoring. Learning environments necessary for acquisition of the selected content necessitate answering to the question "where?" The final question in the model "when?" forms the basis for an interdisciplinary approach that integrates the content, organises the learning experiences, and provides the sequence of activities for implementing the curricula, educational reforms or projects [11].

\section{CONTEMPORARY TEACHING METHODS}

In the traditional approach to teaching, the professor lectures to the room full of students. The students listen, take notes, and solve problems individually. You might see a few bored-looking students jotting down notes, some dozing, and most just being busy with their iPods.

In engineering education, improving lecturing is the critical problem; and the first focus on improving engineering education at all schools should be on improving lecturing.

Most professors begin teaching without so much as five minutes of training on how to do it. Even those who are genuinely concerned about their students and would like to be effective teachers automatically fall back on straight lecturing, which is the only instructional strategy most of them have ever seen. Although they work hard to make the course material as comprehensible and interesting as they can, many of them consistently see only glazed eyes during their lectures, terrible test grades, and evaluations suggesting that the students liked neither the course nor them. Some of them eventually figure out better ways to do their job; others never do, and spend their careers teaching ineffectively.

Teaching methods fostering active and long-term engagement with learning tasks emphasizing conceptual understanding should be used in the study programs for technical teachers in order to make STEM teaching more effective at schools.

Klagenfurt Model of teaching engineering should be used [4]. Accordingly teaching is a process which like any others, is a subject to specific regularities and determined by a series of components throughout its course. These 6 components - teaching goals, teaching materials, psychological structure, social structure, teaching media and teaching methods have a complex interdependent relation- 
ship [4]. Taking account of the named components a technical teacher can build up an effective model of engineering pedagogy for teaching engineering. Some hints introduced below are used at Estonian Centre for Engineering Pedagogy in order to teach engineering more effectively.

Write comprehensive instructional objectives that list the things the students should be able to do (identify, explain, calculate, model, design, critique etc) to demonstrate that they have satisfactorily mastered the knowledge and skills the instructor wants them to master, including high-level thinking and problem-solving skills [4], [5], [6].

Make the objectives available to the students. Design in-class activities and homework to provide practice in the desired skills, and make the tests specific instances of a subset of the instructional objectives [4], [5], [6], [7].

Find out at the beginning of a course what most of the students know and don't know and what misconceptions they have about the subject - start teaching from that point [4].

Recognize that good students vary considerably in motivation, cultural background, interests, and learning style, and teach accordingly. Motivate learning - relate the material being presented to what has come before and what will to come in the same course, to material in other courses, and particularly to the students' personal experience [4], [5].

Provide a balance of concrete information (facts, data, real or hypothetical experiments and their results) and abstract concepts (principles, theories, mathematical models). Balance material that emphasizes practical problemsolving methods with material that emphasizes fundamental understanding [3], [4], [5].

Follow the scientific method in completing, structuring and presenting theoretical material. Provide concrete examples of the phenomena the theory describes or predicts then develop the theory or formulate the mod and show how the theory or mod can be validated, deduce its consequences and present applications [3], [4], [5].

Use pictures, schematics, graphs, and simple sketches liberally before, during, and after the presentation of verbal material. Show films. Provide demonstrations, handson, if possible. Use suitable modern teaching media [2], [3], [15].

Do not fill every minute of class time lecturing and writing on the board. Provide intervals - however brief for students to think about what they have been told [15].

Provide opportunities for students to do something active besides transcribing notes, hold interactive lectures. Small-group activities that take no more than five minutes are extremely effective for this purpose. Active learning is one first step towards problem-based learning [15].

Problem-based learning (PBL) is suited to real-world open-ended problems with multiple respectable solutions, some being better than others and shares qualities with experiential learning activities. PBL is based on learning by doing and even the simplest projects teach to lead, facilitate, record, compromise, cooperate, schedule, discuss, prioritize, organize, plan, research, apply, integrate, evaluate, make decisions. Beyond these basics, we can decide and determine what our students will learn to do and what additional knowledge they will acquire by their research in our choice or design of PBL problems. The research indicates [15] that PBL develops the following skills of students:

- Teamwork;

- Project management and leadership;

- Oral and written communication;

- Emotional intelligence;

- Tolerance for uncertainty;

- Critical thinking and analysis;

- Application of content knowledge;

- Research;

- Decision making;

- Problem solving across disciplines.

In addition to interactive lecturing, have students work individually and in small groups on brief courserelated activities, such as answering questions, setting up problem solutions, completing steps in derivations, interpreting observations or experimental data, estimating, predicting, brainstorming, troubleshooting. Call on several students for responses at the conclusion of each activity then invite volunteers to provide more responses to openended questions, and proceed with the lesson when the desired points have been made. This is active learning [14], [15], [16].

Recognize that students learn best when they perceive a need to know the material being taught. Start with realistic complex problems, let students establish what they know and what they need to find out, and then guide them in finding it out by providing a combination of resources (which may include interactive mini-lectures and integrated hands-on or simulated experiments) and guidance on performing library and Internet research. This is inductive teaching and has a number of variations, including problem-based learning, project-based learning, guided inquiry, discovery learning, and just-in-time teaching [15], [17].

Supplement the traditional content with training in critical and creative thinking, methods of solving openended multidisciplinary problems (which tend to be what practicing engineers spend most of their time dealing with) [18].

Talk to students about different learning styles, both in advising and in classes. Students are reassured to find their academic difficulties may not all be due to personal inadequacies [17].

Assign a combination of individual work and teamwork, structuring the latter to provide assurances of individual accountability for all the work done and following other procedures known to promote good teamwork skills (including communication, leadership, project management, time management, and conflict resolution skills). This is cooperative learning [15], [16], [17].

At Estonian Centre for Engineering Pedagogy cooperative learning is used. Cooperative learning is an instructional approach in which students work in teams on a learning task structured to have the following features [12]:

- Positive independence - there must be a clearly defined group goal (complete the problem set, write the lab report, design the process) that requires involvement of every team member to achieve. If anyone 
fails to do his/her part, everyone is penalized in some manner.

- Individual accountability - each student in the team is held responsible for doing his/her share of the work and for understanding everyone else's contribution.

- Face-to-face promotive interaction. Although some of the group work may be parcelled out and done individually, some must be done interactively, with team members providing one another with questions, feedback, and instruction.

- Appropriate use of interpersonal and teamwork skills. Students should be helped to develop leadership, communication, conflict resolution, and time management skills.

- Regular self-assessment of team functioning. Teams should periodically be required to examine what they are doing well together and what areas need improvement.

\section{CONCLUSIONS}

With his characteristic cleverness, George Bernhard Shaw armed several generations of cynics with his statement: "Those who can, do; those who can't, teach." But in today's world, technical teachers have to be able to do engineering and to teach engineering.

We expect engineers to undergo rigorous training to become proficient. It is logical to require similar rigorous training in the art teaching of technical teachers. As Professor Adolf Melezinek said, "Professional-level engineering teaching is both an art and a science".

\section{REFERENCES}

[1] Melezinek Adolf (1999). Ingenieurpädagogik - Praxis der Vermittlung technischen Wissens, Springer-Verlag, Wien New York, 4th edition.

[2] Melezinek, Adolf (2001). Engineering pedagogy - ingenieurpädagogik: theory and practice of technical teacher training. International Conference on Engineering Education, August 6.-10, 2001, Oslo, Norway.

[3] Melezinek Adolf (1996). On the Didactic Quality of Instruction. The IGIP Qualifications Profile - the European Engineering Educator - ING-PAED IGIP, AECEF Newsletter 3/1996. Available from website http://webold.fsv.cvut.cz/aecef/news/963/melezinek.html (14.12.2006).

[4] Heinze C.D. (1995). „Ingenieurpädagogische Schulen in Europa” In: Melezinek, A. (ed.) „Interdisziplinarität und Internationalität der Universität Klagenfurt - Die Klagenfurter Ingenieurpädagogische Schule", Leuchtturm Verlag (LTV), Alsbach/Bergstraße.

[5] Haug Albert, 30 Years of IGIP - In the Service of Technology Teaching, in Melezinek, A. (Hrsg.) International Society for Engineering Education, Who is Who, Leuchtturm-Verlag, 2001
[6] Schutz Victor K., IGIP 30 Years of Dedicated Work in Teaching Technology, in Litvinenko, V, Melezinek A., Prikhodko V. (Hrsg.), Ingenieur des 21. Jahrhunderts, Referate des 31. Internationalen Symposiums IGIP, Sankt-Petersburg, 2002

[7] IGIP Recommendations for Studies in Engineering Education Sciences, Decided by IGIP International Monitoring Committee on September 11th 2005, Approved by IGIP Executive Committee on September 11th 2005, 37 p., Available on www.igip.org

[8] IGIP Criteria for Accreditation of Engineering Education Studies, Decided by the IGIP International Monitoring Committee on September 11th 2005, Approved by IGIP Executive Committee on September 11th 2005, $16 \mathrm{p}$.

[9] Melezinek Adolf, Ingenieurpädagogische Theorieentwicklung Bestandaufnahme Ingenieurpädagogischer Entwicklungslinien, in Dana Dobrovská (Ed.) New Trends in Engineering Pedagogy, pp. 109 - 126, Prague, 2006

[10] Melezinek Adolf, A Contribution to the Quality of Technology Teaching: IGIP's Qualifications Profile and Professional Register "Der Europäische Ingenieurpädagoge"- "The European Engineering Educator" 'ING-PAED IGIP', in Melezinek, A. (Hrsg.) International Society for Engineering Education, Who is Who, Leuchtturm-Verlag, 2001

[11] Läänemets, U. (2012). Hilda Taba's Heritage: Curriculum Development in Estonia. Proceedings of International Conference on Curriculum Theory and Practice, Ed Kalamees-Ruubel, December 7-8, 2012, Tallinn, Estonia.

[12] Ruutmann, Tiia (2009) . Contemporary teaching methods as the basis of the curriculum for technical teacher training at tallinn university of technology, proceedings of IGIP conference 2009.

[13] Nilson, L. B, "Teaching at its Best - a Research-Based Resource for College Instructors", 2003.

[14] Grayson, L, P, "The Design of Engineering Curricula", UNESCO Studies in Engineering, United Nations, Paris, 1977.

[15] Felder, R. M., "Teaching Engineering in the 21st Century with a 12th-Century Model: How Bright is that?". Chemical Engineering Education, 40(2), 110-113, 2006.

[16] Lang H., Evans D. N., "Models, Strategies and Methods for Effective Teaching", 2006.

[17] Felder, R. M., "Inductive Teaching and Learning Methods: Definitions, Comparisons and Research Bases", Journal of Engineering Education. $95 \quad$ (2), pp 123-138, 2006. http://dx.doi.org/10.1002/j.2168-9830.2006.tb00884.x

[18] Orlich D.C., Harder R.J., Callahan R.C. et al., "Teaching Strategies. A Guide to Effective Instruction”, 2007.

\section{AUTHORS}

Tiia Rüütmann and Hants Kipper are with Tallinn University of Technology, Tallinn, Estonia (e-mails: tiia.ruutmann@ttu.ee, hants.kipper@ttu.ee).

This article is an extended and modified version of a paper presented at the International Conference on Interactive Collaborative Learning (ICL2015), held 20-24 December 2015, in Florence, Italy. 